\title{
Aquatic Macroinvertebrates of Arid and Semi-Arid Ecosystems of Peru
}

\author{
Jerry Arana Maestre ${ }^{1 *}$, Carlos Carrasco Badajoz ${ }^{2,3}$, Pastor Coayla Peñaloza ${ }^{4}$, \\ Carolina Rayme Chalco ${ }^{2,3}$ and Marco Sánchez Peña ${ }^{5,6}$
}

\begin{abstract}
${ }^{1}$ Museo de Historia Natural, Universidad Nacional Mayor de San Marcos, Lima, Perú, ${ }^{2}$ Laboratorio de Biodiversidad y Sistema de Información Geográfica, Universidad Nacional de San Cristóbal de Huamanga, Ayacucho, Perú, ${ }^{3}$ Centro de Investigación en Ecosistemas y Biodiversidad Acuática, Universidad Nacional de San Cristóbal de Huamanga, Ayacucho, Perú, ${ }^{4}$ Laboratorio de Hidrobiología, Universidad Nacional de San Agustín de Arequipa, Perú, Ingeniería Ambiental, Universidad Privada del Norte, Cajamarca, Perú, ${ }^{6}$ Facultad de Ciencias de la Salud, Departamento Académico de Ciencias Biológicas, Universidad Nacional de Cajamarca, Perú
\end{abstract}

\section{OPEN ACCESS}

Edited by:

Eugenia López-López, Instituto Politécnico Nacional de México (IPN), Mexico

Reviewed by: Luiz Ubiratan Hepp, Federal University of Mato Grosso do

Sul, Brazil

Wynand Malherbe,

North-West University, South Africa

*Correspondence:

Jerry Arana Maestre jaranam@unmsm.edu.pe

Specialty section:

This article was submitted to

Freshwater Science,

a section of the journal

Frontiers in Environmental Science

Received: 26 January 2021 Accepted: 20 July 2021 Published: 30 July 2021

Citation: Arana Maestre J, Carrasco Badajoz C, Coayla Peñaloza $P$, Rayme Chalco $C$ and Sánchez Peña M (2021) Aquatic Macroinvertebrates of Arid and Semi-

Arid Ecosystems of Peru.

Front. Environ. Sci. 9:658940. doi: 10.3389/fenvs.2021.658940
Peru is one of the megadiverse countries worldwide, displaying a great diversity of ecosystems due to its tropical location, marine currents, and complex relief, which jointly define environments differentiated by altitude and climatic conditions. The arid and semi-arid ecosystems comprising xeric and Andean shrublands, coastal deserts, and coastal hills, illustrate this diversity of ecosystems; these stretch over $177358 \mathrm{~km}^{2}$, representing $13.8 \%$ of the Peruvian territory. Several studies on aquatic macroinvertebrates are being conducted in these ecosystems; although not so numerous yet, have shown a rise in recent years. The objective of this work was to determine the composition and distribution of aquatic macroinvertebrates in the arid and semi-arid ecosystems of Peru. To this end, we conducted a literature survey; the articles and theses found were reviewed and analyzed. The following keywords were used: macroinvertebrates, macrozoobenthos, bioindicators, diversity of aquatic organisms, and water quality; we used the Google Academic search engine, Scopus, Web of Science, ResearchGate and the thesis repositories of Peruvian universities, additionally a thesis from the University of Barcelona. Of a total of 53 sources of information, 38 are theses and 15 are scientific articles conducted from 1992 to 2020, referring to studies conducted at elevations ranging from 0 to 3,831 $\mathrm{m}$ asl. Most studies were conducted at the Lima and La Libertad departments, resulting in 20 and 10 publications, respectively. The topics addressed most frequently were bioindication, biodiversity, taxonomy, and distribution. Most theses were carried in the Universidad Nacional de Trujillo and the Universidad Nacional Mayor de San Marcos, with 12 and 10 theses, respectively. The period 2011-2020 records the largest number of publications (40). According to the type of aquatic ecosystem, rivers (38) were the systems most intensively studied, followed by coastal wetlands (14) and lagoons (2); to note, one thesis studied two types of ecosystems. Specimens were collected mainly with the Surber and D nets; as a result, seven phyla, 10 classes, 39 orders, and 118 families were reported. The highest richness of families corresponds to rivers (110), followed by coastal wetlands (57), and lagoons (12). The western hydrographic slope recorded the highest richness at phylum, class, order, and family levels, likely because most investigations were conducted in this slope. On the other hand, the phyla Cnidaria, Nematoda, and Nematomorpha were not recorded in the 
eastern slope, which showed fewer orders (19) relative to the western slope (39). A similar trend is observed at the family level: of the 118 families recorded, 59 were reported for the eastern slope. The most common families at both sides were Chironomidae, Baetidae, Simuliidae, Elmidae, Hydrophilidae, Libellulidae, Physidae, Dytiscidae, Ceratopogonidae, Coenagrionidae, Hydroptilidae, Hydropsychidae, and Tipulidae. Separately, the most common families in all types of aquatic ecosystems were Chironomidae, Baetidae, and Dytiscidae. It is recommended to further promote studies on macroinvertebrates living in the eastern slope, addressing taxonomic, and ecological topics, as well as broadening the approach to an integral ecosystem view. Finally, the biotic indices should be calibrated and validated for the main hydrographic basins. This work is an initial effort to review, systematize, analyze, and gather the results of studies on aquatic macroinvertebrates in Peru, particularly in arid and semi-arid ecosystems.

Keywords: coastal wetland, lagoons, insects, benthos, rivers

\section{INTRODUCTION}

The diversity of landscapes, natural regions, biomes, life zones, ecoregions, altitudinal zones, and ecosystems make of Peru one of the megadiverse countries of the world (MINAM, 2019a). The high diversity of ecosystems in this country derives from its tropical location, exposure to marine currents, and complex orography, which define environments influenced by their particular altitude and climatic conditions. Arid and semi-arid ecosystems comprising xeric and Andean shrublands, coastal deserts, and coastal hills, exemplify this diversity, spreading across some $177,358 \mathrm{~km}^{2}$, equivalent to $13.8 \%$ of the Peruvian territory (MINAM, 2019b).

Arid and semi-arid ecosystems are highly important from the economic standpoint, because many anthropogenic activities take place in them, such as agriculture, industry, etc. Vidal-Abarca et al. (2004) points out that these ecosystems have become increasingly relevant for understanding the behavior of climate variability in the world. The large urban centers of Peru are located in arid and semi-arid areas along the Peruvian coast; the most prominent example is the capital city, Lima, that is home to over ten million inhabitants (INEI, 2020). The largest agricultural area of Peru, where export crop products are grown, including asparagus, grape, cotton, artichoke, mango, organic banana, and others (Velazco and Pinilla, 2018), is located in coastal zones. This results in high water demand, frequently causing hydric stress processes that are currently affecting water availability in these regions (Oré et al., 2012; Salazar, 2012; Urteaga-Crovetto, 2016).

The present study is of utmost importance to communicate to the scientific community, both in Peru and internationally, the distribution of macroinvertebrate communities in Peru, highlighting the departments where research has been conducted, as well as the research topics addressed. The information gathered in this research study represents the first account about this group of organisms at country level; it will allow to better understand the diversity and distribution of these organisms in Peru, and the current and future impact of anthropogenic activities on local ecosystems. This information will guide the development of predictive models on the ecological conditions of arid and semi-arid ecosystems, among the central topics.

The xeric shrubland comprises shrub associations of columnar cacti interspersed with ephemeral herbs. The vegetation is sparse (30-60\%), isolated, xeric, thorny, and stunted, with a poorly diverse floristic composition, but with high endemism levels. Shrubs and cacti may reach up to $4 \mathrm{~m}$ high. This is located mainly in valleys, on steep slopes between 300 and 2,000 m above sea level. It covers an area of approximately $0.05 \%(64,175.98 \mathrm{ha})$ of Peru in the departments of Tumbes, Piura, Lambayeque, and La Libertad (MINAM, 2019a).

There is also the widespread Andean shrubland, which includes three types of shrub vegetation (montane, Andean grasslands (puna), and Andean shrublands) thriving in an altitudinal range from 1,500 to $4,500 \mathrm{~m}$ a.s.l. It is characterized by woody and shrub vegetation of variable composition and structure. The dry-puna shrubland includes extensive areas of "tola" (Parastrephia spp.), as well as Lepidophyllum quadrangulare and Baccharis spp. The montane shrubland shows sclerophyll shrubs and short trees of up to $2 \mathrm{~m}$ high covered by epiphytes. The Andean shrubland is dominated by shrubs, with scattered trees and cactaceae. The Andean shrubland covers an approximate area of 7.96\% (10,304,035.94 ha) of Peru in the departments of Cajamarca, La Libertad, Piura, Ancash, Lima, Junín, Pasco, Huancavelica, Ayacucho, Apurímac, Cusco, Arequipa, Moquegua, Puno, Tacna, San Martín, Amazonas, and Huánuco (MINAM, 2019a). The importance of the Andean shrubland lies in its contribution to climate regulation, water cycle, and soil retention, besides being the habitat for multiple species. The greatest threats are mining and agriculture, overgrazing, and shrub exploitation for firewood (MINAM, 2019b).

On the other hand, the coastal desert is an arid-to-hyperarid ecosystem with areas mostly devoid of vegetation that are made up of sandy soils or rocky outcrops scattered across flat and hilly areas. It stretches from beaches and coastal cliffs to the first foothills of the western slopes. The dominant plant communities in coastal deserts include Tillandsia spp., cactaceae, and dry ravine vegetation, among others. Altitudinal ranges vary 
latitudinally from sea level: to the north, coastal deserts reach up to $800 \mathrm{~m}$ a.s.l.; in central regions, up to $1,800 \mathrm{~m}$ a.s.l.; and in southern Peru, up to 2,500 m a.s.l. The coastal desert covers an area of approximately $5.49 \%(7,107,338.20 \mathrm{ha})$ of Peru in the departments of Piura, Lambayeque, La Libertad, Ancash, Lima, Ica, Arequipa, Moquegua, and Tacna. Spread along the coastal and maritime coastline are coastal wetlands, defined as areas covered or saturated with water, under a natural or artificial, permanent or temporary water regime, and that house a unique assemblage of biological communities (MINAM, 2019a). The coastal desert is seriously threatened, especially because it concentrates $55.9 \%$ of human populations, mainly in everexpanding cities such as Lima, Trujillo, and Ica (MINAM, 2019a).

Finally, coastal hills are ephemeral xeric plant formations that include herbaceous plants and scattered trees. These are rich in plant endemisms, seasonally covering extensive desert areas in hills exposed to winter fog and with relative humidity above $80 \%$, from 100 to about $1,000 \mathrm{~m}$ a.s.l. These formations contain many herbaceous plants that are wild relatives of cultivated plants: potato, tomato (Solanum spp.), and pumpkin (Sicyos spp.) (MINAM, 2019a). Its current threats include urban expansion, land use by cement factories, and the potential impact of climate change (MINAM, 2019b).

Studies on aquatic macroinvertebrates are ongoing in these ecosystems. Although not abundant, the number of studies has increased steadily in recent years. Aquatic macroinvertebrates are invertebrate communities of sizes larger than $0.5 \mathrm{~mm}$. Their composition reflects the status of ecosystems and are extensively used in environmental monitoring and protection programs (Roldán-Pérez, 2016). In the Neotropics, the current knowledge of macroinvertebrates is still scarce, with information published in a number of European, North American, and South American journals (Roldan and Ramirez, 2008). For this reason, our aim was to review the composition and distribution of aquatic macroinvertebrates in arid and semiarid ecosystems of Peru.

\section{MATERIALS AND METHODS}

We conducted a review and analysis of the literature in scientific articles and degree theses addressing aquatic macroinvertebrates of arid and semi-arid ecosystems of Peru over the past 28 years. We used the following keywords: macroinvertebrates, macrozoobenthos bioindicators, diversity of aquatic organisms, and water quality. We used the Google Academic search engine, Scopus, Web of Science, ResearchGate, and searched the theses repositories of Peruvian universities and the University of Barcelona (Spain), including undergraduate and postgraduate theses, as well as publications in indexed journals. From the information obtained, we selected those studies that were conducted in arid and semi-arid ecosystems of the eastern and western Peruvian slopes (Figure 1).

The data of the 53 references found were entered in an Excel 2016 spreadsheet; the data entered included studies by universities, year of publication, research works by departments, aquatic systems, subjects studied, and taxonomical classification of aquatic macroinvertebrates by phylum, class, order, and family. Frequencies and percentages were calculated with the statistical program IBM SPSS Statistic 26.

In Peru, the distribution of ecosystems in the ecological map of Peru [as prepared by (ONERN, 1976)] classifies Peruvian ecosystems into 10 humidity-based provinces, five of them corresponding to arid and semi-arid ecosystems, namely dryland, hyperarid, perarid (these three considered as very arid ecosystems), arid, and semi-arid. The analysis of studies in the present work considered the five humidity-based provinces mentioned above. In 2015, based on information from the ecological map of Peru (ONERN, 1976), the Peruvian Ministry of Environment (MINAM, 2019a) developed the national bioclimatic map, which groups ecosystems into five bioclimatic regions, considering only one arid and one semi-arid region, plus three humid regions. According to the vegetation cover map of Peru (MINAM, 2015a), arid and semi-arid ecosystems account

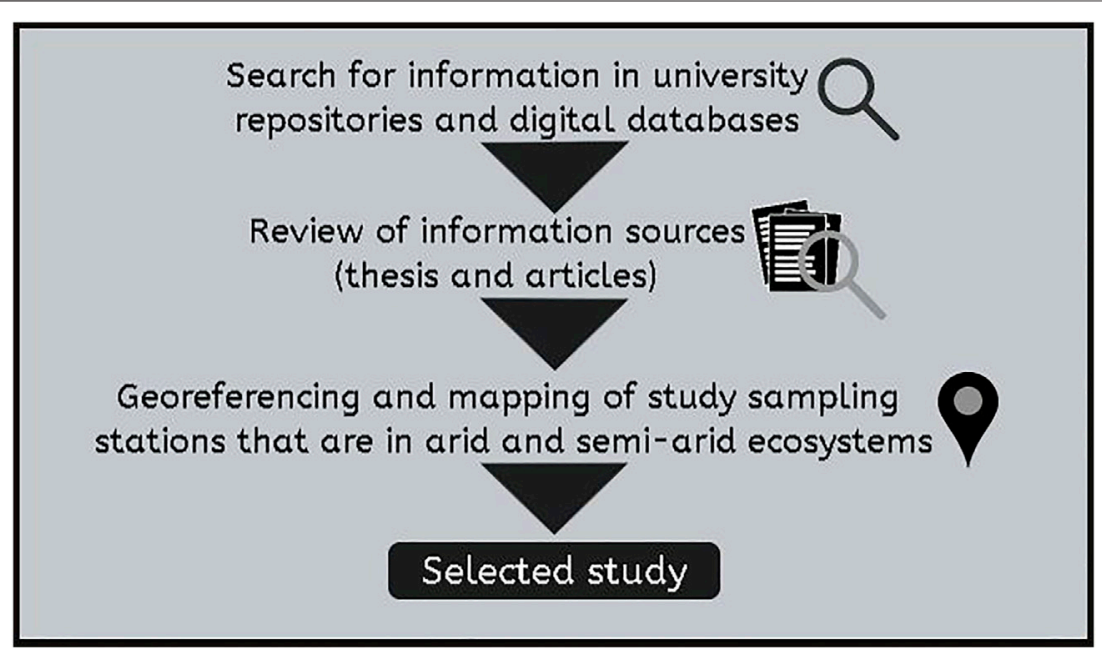

FIGURE 1 | Methodology for the selection of studies on aquatic macroinvertebrates in arid and semi-arid ecosystems of Peru. 


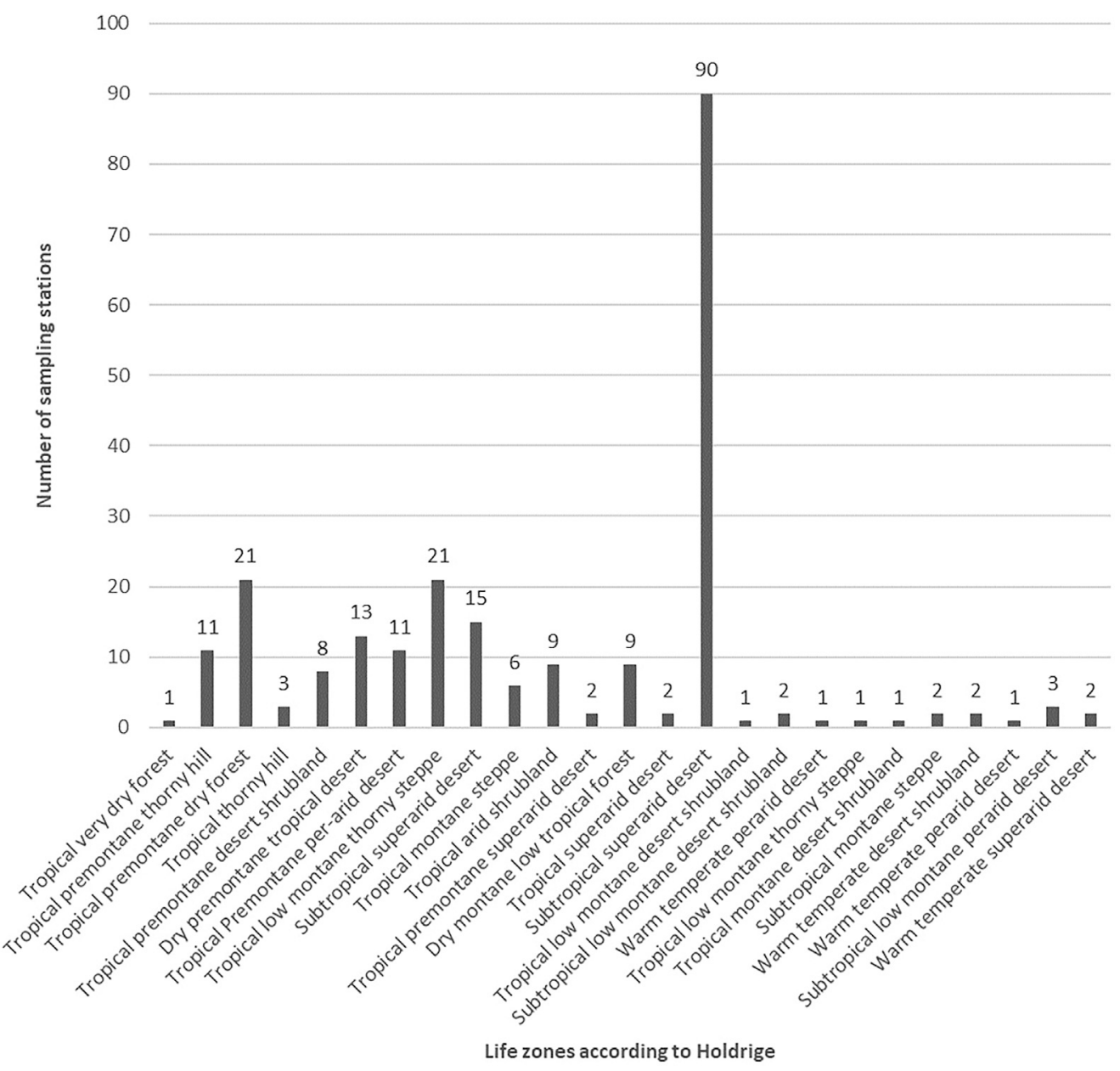

FIGURE 2 | Number of sampling stations by life zone studied between years 1992-2020.

for $10.13 \%$ of the national territory, making them highly important ecosystems in terms of national diversity.

To determine the life zones of the ecosystems studied (Holdridge, 1987), the monitoring stations of the 53 works gathered were located in the national map of life zones. To this end, the georeferencing units of the systems used in each work were standardized and then converted to the UTM WGS 84 system and the coordinates were superimposed on the Peruvian national map of life zones (GEO GPS PERU, 2015) and the map of slopes of the Peruvian Ministry of the Environment (GEO GPS PERU, 2014). The data were processed in Arc GIS 10.5.

\section{RESULTS AND DISCUSSION}

\section{Studies by Life Zones}

From the 53 studies analyzed, a total of 238 sampling stations were geo-referenced. These were superimposed on the map of life zones of Peru; from it, all studies are located in 25 life zones. Figure 2 shows the number of sampling stations included in all studies and distributed in the 25 life zones. The life zone most frequently evaluated at the national level, with a total of 90 stations, was the subtropical dry desert located mostly in the department of Lima. Second, the life zones with the highest number of stations were the tropical premontane dry forest, located in the departments of La Libertad and Cajamarca, and the tropical low montane thorny steppe, in the departments of La Libertad and Lima; each with 21 stations. The other life zones have less than 15 stations each.

Table 1 shows the number of life zones monitored in each department. It is evident that, although the department of Lima has the largest number of sampling stations, La Libertad has the greatest diversity of life zones, with a total of 12 . As the department of La Libertad is located to the north and close to Ecuador, it shows a greater diversification of arid and semi-arid ecosystems. The sampling station evaluated at the highest altitude was located at 3,831 $\mathrm{m}$ above sea level; this zone comprises a tropical montane steppe; according to its physiographic characteristics, it is a high mountain corresponding to the high-montane altitudinal belt (MINAM, 2019a). The stations evaluated at the lowest altitude were located from 0 to $5 \mathrm{~m}$ a.s.l. in the department of Lima, corresponding to the subtropical 
TABLE 1 | Distribution of life zones per department in the 53 studies between years 1992-2020.

\begin{tabular}{|c|c|c|}
\hline Department & Life zone & $\begin{array}{c}\text { Number of life } \\
\text { zones }\end{array}$ \\
\hline Amazonas & $\begin{array}{l}\text { Tropical premontane dry forest } \\
\text { Tropical thorny hill } \\
\text { Tropical very dry forest }\end{array}$ & 3 \\
\hline Cajamarca & $\begin{array}{l}\text { Dry montane low tropical forest } \\
\text { Tropical premontane dry forest } \\
\text { Tropical premontane thorny hill }\end{array}$ & 3 \\
\hline La Libertad & $\begin{array}{l}\text { Tropical premontane thorny hill } \\
\text { Tropical premontane desert shrubland } \\
\text { Tropical premontane dry forest } \\
\text { Dry montane low tropical forest } \\
\text { Tropical premontane perarid desert } \\
\text { Dry premontane tropical desert } \\
\text { Tropical low montane thorny steppe } \\
\text { Subtropical superarid desert } \\
\text { Tropical montane steppe } \\
\text { Tropical low montane thorny steppe } \\
\text { Tropical arid shrubland } \\
\text { Tropical premontane superarid desert }\end{array}$ & 12 \\
\hline Ancash & $\begin{array}{l}\text { Dry premontane tropical desert } \\
\text { Dry montane low tropical forest }\end{array}$ & 2 \\
\hline Piura & $\begin{array}{l}\text { Subtropical superarid desert } \\
\text { Tropical arid shrubland } \\
\text { Tropical premontane superarid desert } \\
\text { Tropical superarid desert }\end{array}$ & 4 \\
\hline Lima & $\begin{array}{l}\text { Subtropical dry desert } \\
\text { Tropical montane steppe } \\
\text { Tropical low montane thorny steppe } \\
\text { Subtropical superarid desert } \\
\text { Tropical low montane desert shrubland } \\
\text { Tropical premontane per-arid desert } \\
\text { Tropical premontane desert shrubland } \\
\text { Tropical montane desert shrubland } \\
\text { Subtropical low montane desert } \\
\text { shrubland }\end{array}$ & 9 \\
\hline Ica & $\begin{array}{l}\text { Subtropical dry desert } \\
\text { Tropical low montane thorny steppe }\end{array}$ & 2 \\
\hline Ayacucho & Subtropical montane steppe & 1 \\
\hline Arequipa & $\begin{array}{l}\text { Subtropical dry desert } \\
\text { Warm temperate perarid desert } \\
\text { Warm temperate desert shrubland } \\
\text { Subtropical low montane perarid desert } \\
\text { Warm temperate superarid desert }\end{array}$ & 5 \\
\hline
\end{tabular}

superarid desert life zone. The ecosystems evaluated in these regions are coastal wetlands belonging to the complex coastal fringe physiography (MINAM, 2019a).

Peru includes three macro hydrographic slopes that host all rivers, namely the Pacific slope, the Atlantic (Amazonas) slope, and Lake Titicaca slope (MINAM, 2015b). As shown in .Supplementary Figure S1 Map of Peruvian slopes showing the sampling stations in the 53 studies (1:200,000 scale), when locating the sampling stations of the studies considered, it is apparent that most of the freshwater ecosystems evaluated flow into the Pacific slope, except for the stations in the departments of Cajamarca and Amazonas, which flow into the Atlantic slope. None of the stations flow into Lake Titicaca. To note, the present study represents the first report on the ecosystemic distribution of this group of organisms in Peru.

\section{How Much has Been Investigated?}

Of a total of 53 sources of information covering the years 1992-2020 and addressing aquatic macroinvertebrates in arid and semi-arid ecosystems, $71.7 \%$ were academic theses; of these, $58.5 \%$ (31) were undergraduate theses and $13.2 \%$ (7) were postgraduate theses; $28.3 \%$ (15) corresponded to scientific articles (Figure 3).

To note, theses are generally considered to be gray scientific literature, in the sense that the information is intended only to be awarded a professional degree, allowing the author to obtain a license to conduct professional activities, but not published in a scientific article. As this is a widespread reality for many Peruvian universities, there is a large number of academic theses on macroinvertebrates relative to scientific articles (FerrerasFernández et al., 2015). From the information gathered in the present study, we observed that there are few theses (6) that have been published as scientific articles; thus, a huge amount of valuable information is hidden or difficult to access.

Figure 4 shows that the departments with the largest number of studies conducted on aquatic macroinvertebrates in arid and semi-arid ecosystems are Lima and La Libertad, with 37.7 and $18.9 \%$ of publications, respectively, while Cajamarca $(9.4 \%)$, Callao (7.5\%), and Piura (5.7\%) contributed $10 \%$ or less, and Ica, Arequipa, Ancash, Arequipa-Ayacucho, La LibertadCajamarca, Lima-Callao, and Amazonas have very few studies. The larger number of studies have been conducted in Lima and La Libertad because a large portion of the territory comprises arid and semi-arid areas (Guerrero et al., 2019). It should be noted that some of the works were carried out in two departments (LimaCallao, Arequipa-Ayacucho, and La Libertad-Cajamarca). On the other hand, it is worth mentioning that Callao is the only constitutional province of Peru that has its own autonomous government (Municipalidad Provincial del Callao, 2013); therefore, the results of the studies carried out in this province are considered as corresponding to a department. In the case of the description of life zones, the department of Lima comprises the studies conducted in Lima, Callao, and Lima-Callao, since geographically they belong to the same ecological regions; on the other hand, the studies conducted for Arequipa-Ayacucho and $\mathrm{La}$ Libertad-Cajamarca were processed separately, i.e., by department (Figure 4).

Aquatic macroinvertebrates are important in arid ecosystems (Scheibler, 2008), which are confined to a small part of the Peruvian territory. The higher frequency of studies conducted in Lima reflects the existence of a larger number of universities with professional degrees compatible with the study of macroinvertebrates, in addition to the specialization of advisors, who encourage the elaboration of theses addressing subjects on related areas and lines of research.

The topics most frequently addressed in relation to aquatic macroinvertebrates in arid and semi-arid ecosystems of Peru are bioindication (49.1\%) and biodiversity issues (34\%), whereas taxonomy, distribution, biological control, and toxicity are less frequent, accounting for less than 17.5\% (Figure 5).

Bioindication and biomonitoring have received growing attention in recent years, a trend likely to continue in the future. To a certain extent, the focus on these topics derives 


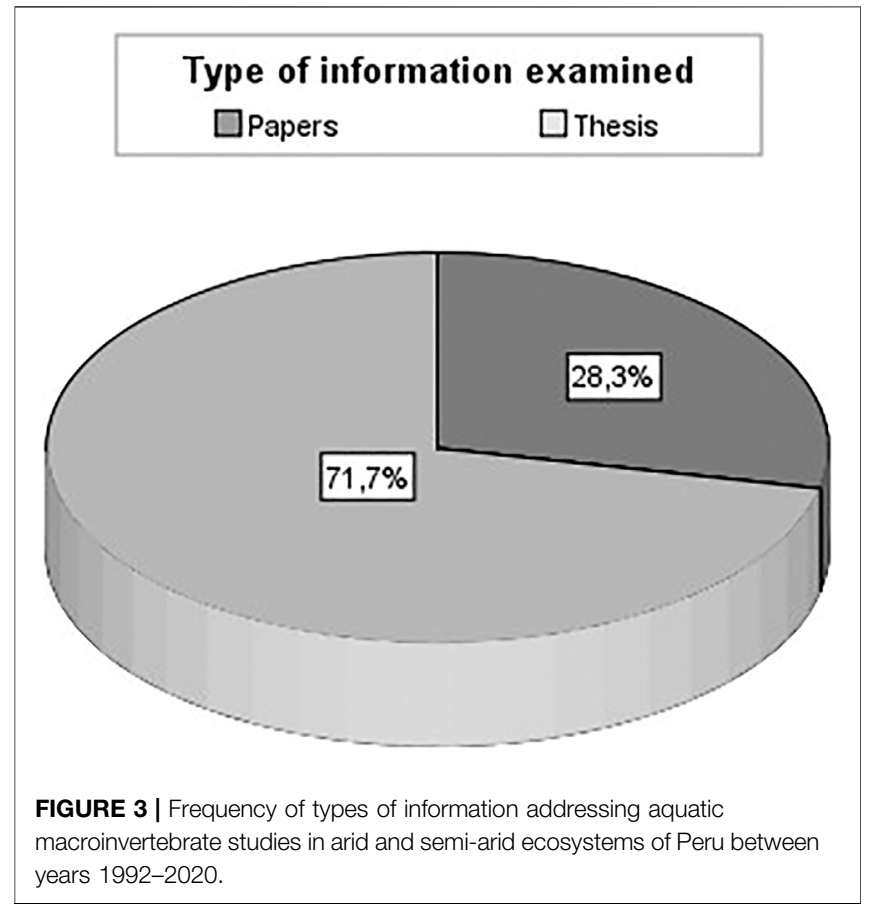

from the interest in objectively measuring the effect of human activity on water resources as a result of increased pressure when managed as sources of goods and services for the growing human population. This is particularly evident for urban areas, the number of which has increased dramatically in recent decades (Montgomery and Elimelech, 2007; McDonald et al., 2011). Rivers have been the most heavily impacted aquatic environments, given the extraction of large volumes of water and the disposal of untreated wastewater into them, both of which have led to their deterioration (Da Cruz and Ríos-Touma, 2018; Ríos-Touma and Ramírez, 2019). The value of macroinvertebrates to estimate the ecological quality of aquatic ecosystems to quantify the effect of pollution has been demonstrated (Roldán-Pérez, 2016; Domínguez et al., 2020). Therefore, a high percentage of the studies reviewed uses indices such as the Biological Monitoring Working Party (BMWP) adapted to countries such as Colombia, and the Andean Biotic Index (ABI), used for rivers above 2,000 $\mathrm{m}$ a.s.l. (Ríos-Touma et al., 2014). Few investigations have adapted these indices to the particular conditions of the water resources studied, which is necessary given the heterogeneous environmental conditions involved.

On the other hand, the biodiversity topic, which is closely related to taxonomy, has been addressed because of the need to generate additional scientific information on macroinvertebrates in Latin America, Peru included, as this information is scarce relative to data for other continents (Ramírez and Gutiérrez-Fonseca, 2014). In our view, this topic will also be addressed more frequently in the coming years, aiming to determine the species composition, richness, and abundance, which will set a solid base for the development

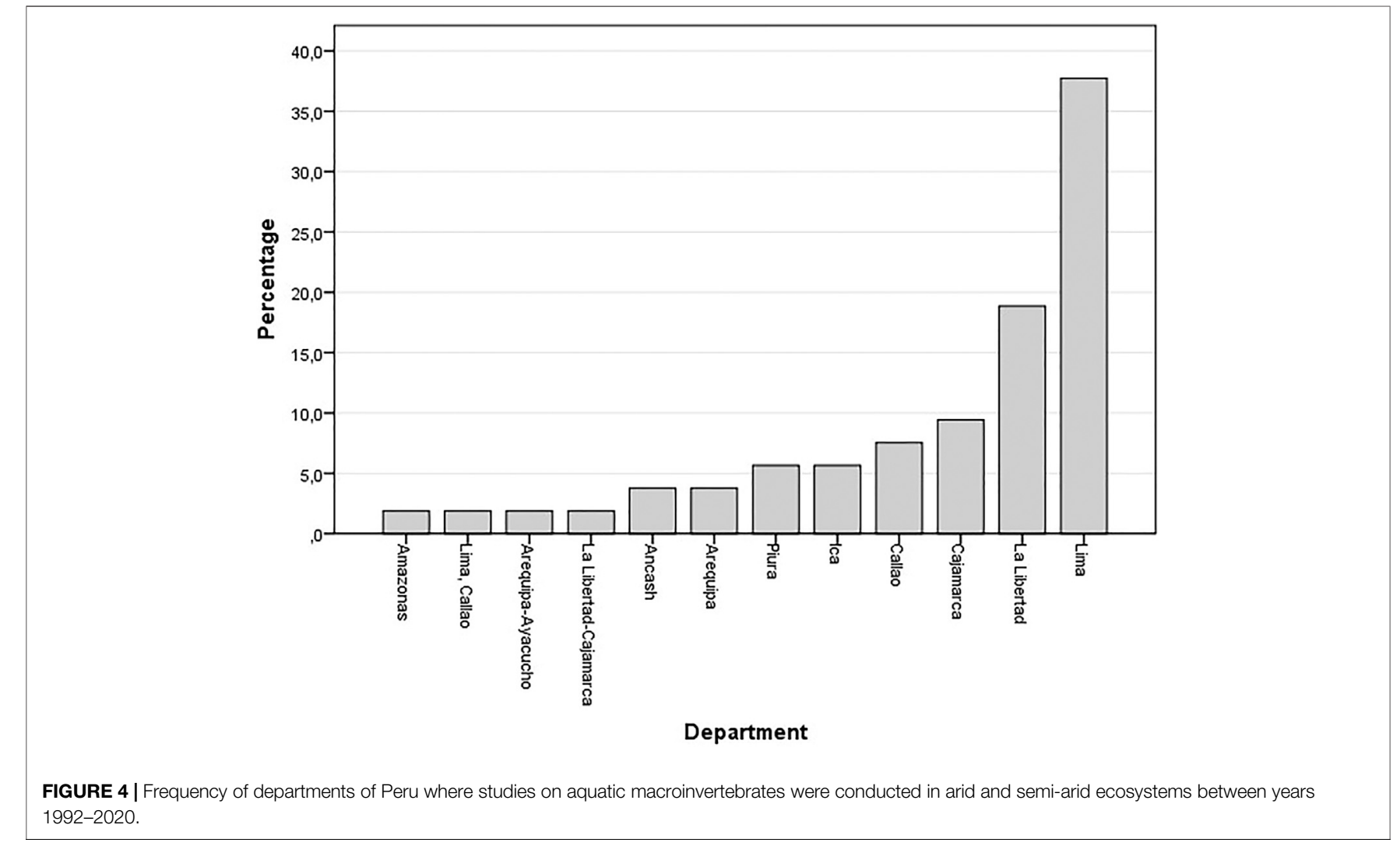




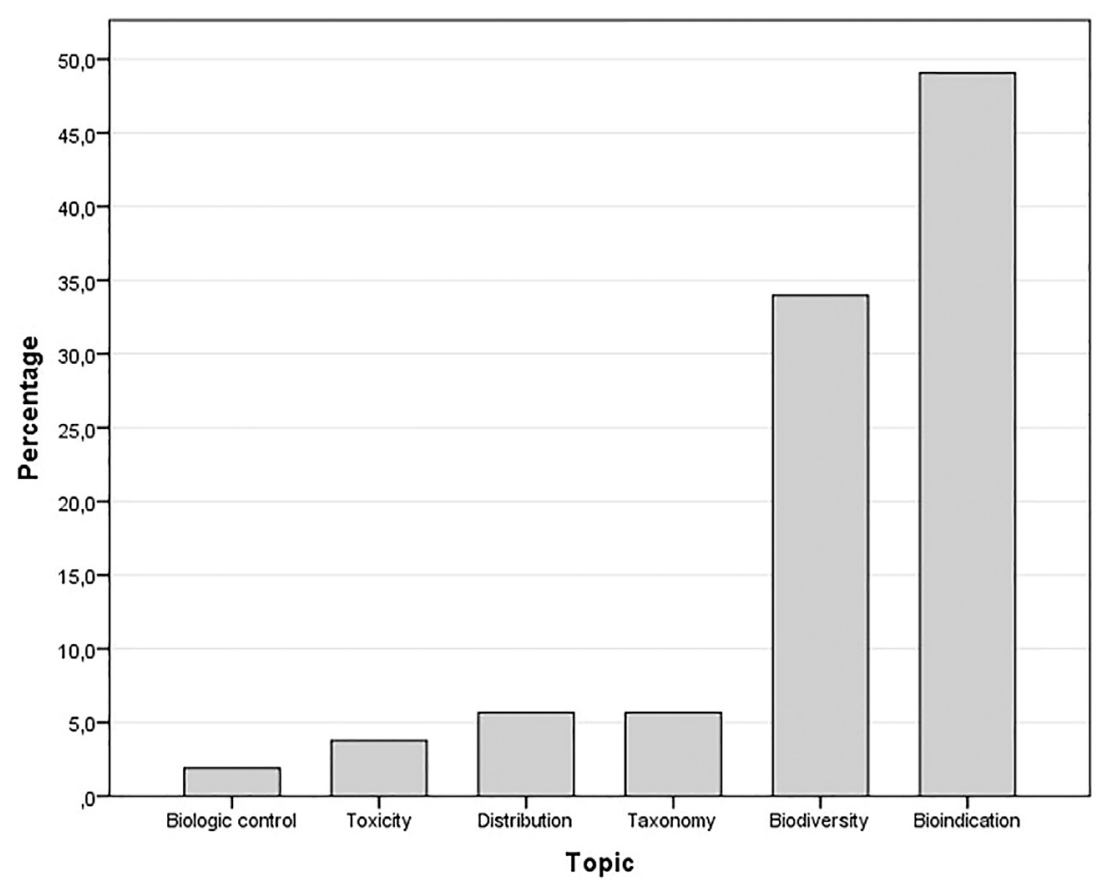

FIGURE 5 | Frequency of topics on aquatic macroinvertebrates in arid and semi-arid ecosystems of Peru between years 1992-2020.

of adaptations and calibration of biological quality indices suitable for the Peruvian rivers.

The studies reviewed have addressed mainly macroinvertebrates as components of rivers, accounting for $70.4 \%$, contrasting with $29.6 \%$ for coastal lagoons and wetlands (Figure 6). Peru is home to 12,201 lagoons, 31.9\% in the Pacific slope that includes mostly arid and semi-arid ecosystems, $70 \%$ in the Atlantic slope, and only $6.9 \%$ in the Titicaca basin (Masson, 2002). As regards rivers, more than one thousand are reported flowing across 53 basins, mainly on the Pacific slope and only during the rainy season in most cases (Brack and Mendiola, 2000). The greatest research effort focused on macroinvertebrates in lotic systems, probably because these are easier to access for characterization. Also, the negative impacts of urban centers are most frequently observed in rivers, hence the interest in determining their ecological status aiming to set conservation measures, which has yet to be achieved in most cases. The concern about rivers affected by human populations has led to concepts describing the changes associated with what is known as the "urban river syndrome" (Meyer et al., 2005; Walsh et al., 2005; Roy et al., 2016), describing changes in hydrogeology, increased nutrient loads, and loss of native fauna. Studies addressing macroinvertebrates in coastal lagoons and wetlands are less frequent. Therefore, these studies should be promoted to get detailed knowledge about the characteristics of macroinvertebrates and the functioning of these ecosystems, as well as the adaptation and calibration of indices to conduct biomonitoring with tangible results, as in the case of lotic systems.

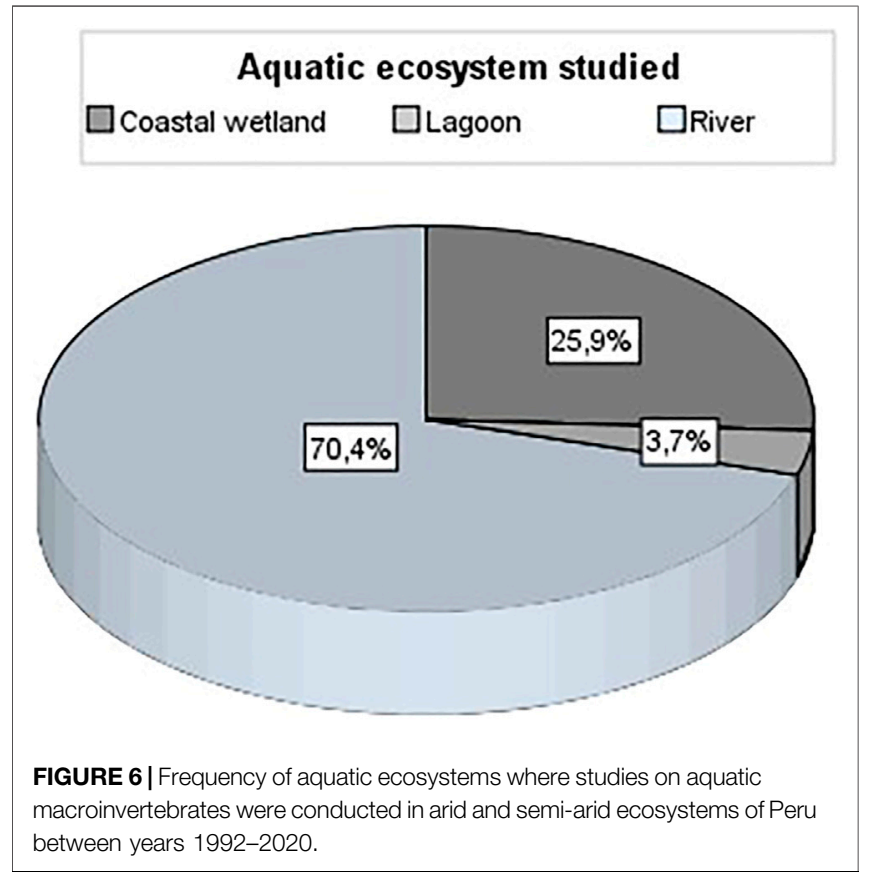

\section{What Institutions Are Conducting Research?}

According to the online data reviewed, early research on aquatic macroinvertebrates in the arid and semi-arid ecosystems of Peru started in the 1990's. Some theses works were probably conducted 


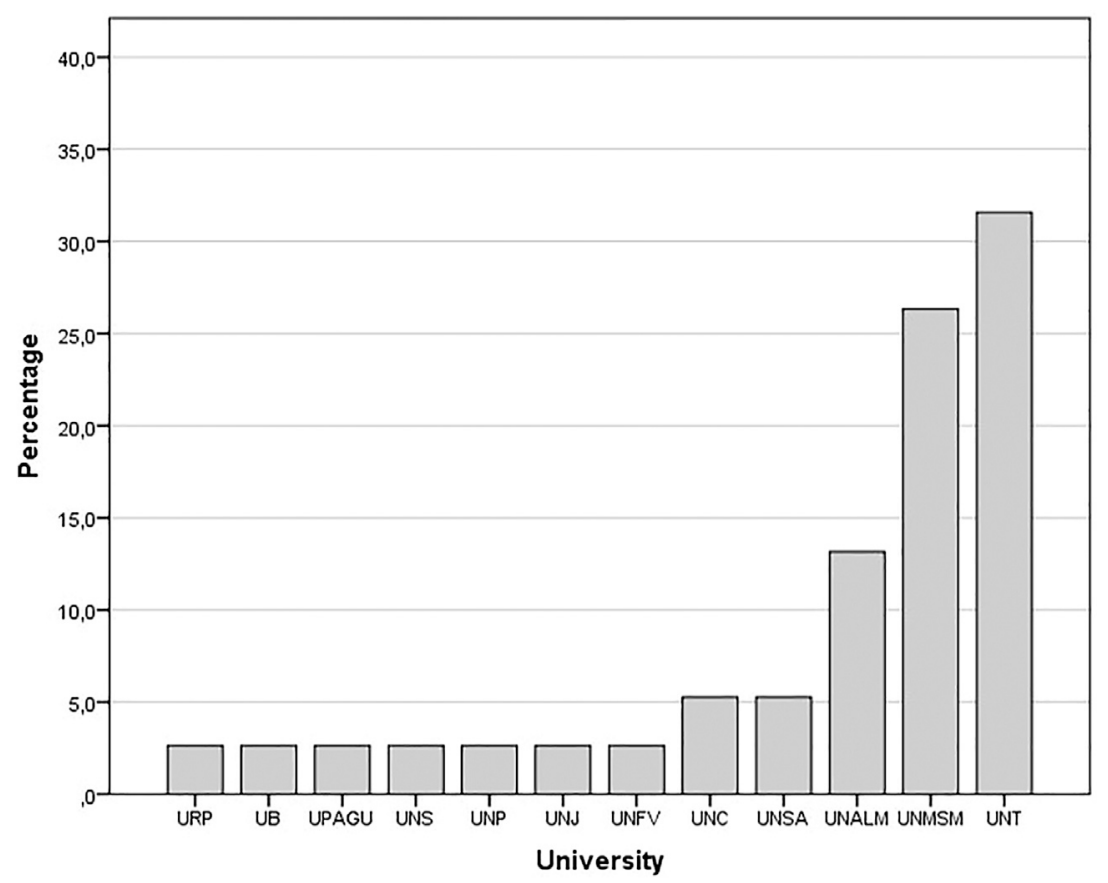

FIGURE 7 | Universities that conducted research on aquatic macroinvertebrates in arid and semi-arid ecosystems between years 1992-2020, ranked according to the percentage of studies.

before this decade, which may be available at college libraries, thus hampering their analysis and inclusion in the present revision. Today, eleven Peruvian universities are conducting this type of research: Universidad Ricardo Palma (URP); Universidad Privada Antonio Guillermo Urrelo (UPAGU); Universidad Nacional de Trujillo (UNT); Universidad Nacional de San Agustín de Arequipa (UNSA); Universidad Nacional del Santa (UNS); Universidad Nacional de Piura (UNP); Universidad Nacional Mayor de San Marcos (UNMSM); Universidad Nacional Federico Villarreal (UNFV); Universidad Nacional de Cajamarca (UNC); Universidad Nacional Agraria la Molina (UNALM) and Universidad Nacional de Jaén (UNJ). Besides these institutions, the University of Barcelona (UB), Spain, also carried out a study on these ecosystems (Figure 7). Most studies (71.7\% being theses) were conducted by researchers affiliated to Universidad Nacional de Trujillo; Universidad Nacional Mayor de San Marcos, and Universidad Nacional Agraria La Molina, these being the institutions that contributed the most to the current knowledge. These are followed by Universidad Nacional Cajamarca and Universidad Nacional de San Agustín de Arequipa (10.6\% of total theses). The participation of the rest of the universities was scarce, with a single research study (thesis) on macroinvertebrates recorded for the period analyzed (Figure 7). These results show the research activities of Peruvian universities in these ecosystems. The few studies on the subject of interest at most universities face serious limitations that restrain scientific productivity (Ramírez and GutiérrezFonseca, 2014). Besides, in the Peruvian universities there is little communication between researchers of the different universities; this is likely one of the obstacles for conducting research in universities with a small contribution to the training and professional development of scientists, added to the scarce availability of economic funds for research. Thus, a greater collaboration between them will certainly improve the communication and collaboration between universities (Ramírez and Gutiérrez-Fonseca, 2020). In this paper, the inclusion of the information by department and university will make possible seeking national and international funds for the conduct of studies with international partnership, such as the Universidad Nacional de Cajamarca (National University of Cajamarca; Programa de Cooperación Interuniversitaria e Investigación Científica entre España e Iberoamérica, 2011; VLIR-UOS, 2018).

Regarding the number of publications (theses and scientific articles), a significant increase occurred in the past decade (Figure 8). In the 1990's, little work was conducted $(5.7 \%$ of the total recorded), which increased in the period 2001-2010 (18.9\%); the past decade was the period when most studies were carried out $(75.5 \%$ of the total), mainly undergraduate theses. This boost in research productivity over the past 10 years probably reflects the effort made by some of the universities to finance research and training of human resources, not to mention the increased access to the information in some universities by acquiring the Web of Science database service, which is available to the university community. Also important is the development of Limnology, mainly in Colombia, which paved the way for other Latin American countries (Roldán, 2020). These 53 research studies have contributed valuable information about macroinvertebrate communities of arid and semi-arid ecosystems of Peru, as research projects to advance the 


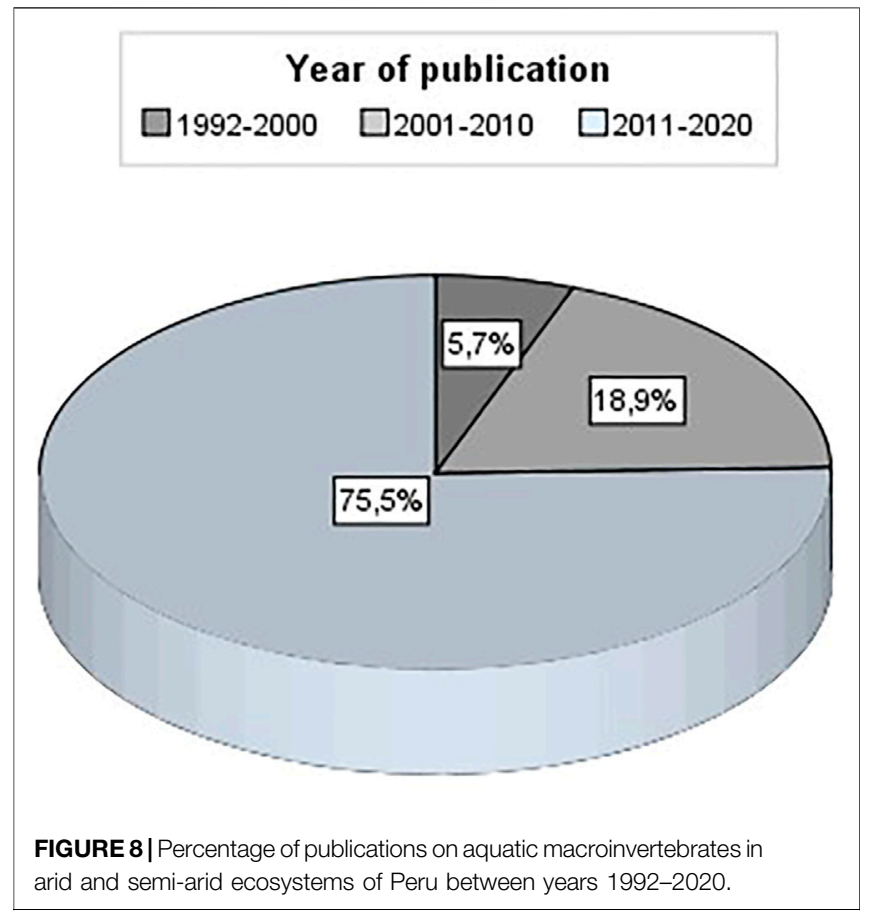

TABLE 2 | Classes of macroinvertebrates by hydrographic slope and aquatic ecosystem, according to research studies carried out between years 1992-2020.

\begin{tabular}{|c|c|c|c|c|c|}
\hline \multirow[b]{2}{*}{ Phylum } & \multicolumn{2}{|c|}{ Slope } & \multicolumn{3}{|c|}{ Aquatic ecosystem } \\
\hline & Western & Eastern & $\begin{array}{l}\text { Coastal } \\
\text { wetland }\end{array}$ & Lagoon & River \\
\hline Annelida & & & & & \\
\hline Arthropoda & & & & & \\
\hline Cnidaria & & & & & \\
\hline Mollusca & & & & & \\
\hline Nematoda & & & & & \\
\hline Nematomorpha & & & & & \\
\hline Platyhelminthes & & & & & \\
\hline
\end{tabular}

: Presence

knowledge of these aquatic ecosystems have become a priority (Hankel et al., 2018), facilitating the identification and classification of freshwater species, as well as a deeper insight on their life histories (Contador et al., 2012).

\section{Key Findings in Arid and Semi-Arid Ecosystems of Peru}

The information sources reviewed resulted in a total of seven phyla, 10 classes, 39 orders, and 118 families of aquatic macroinvertebrates recorded in arid and semi-arid ecosystems of Peru, with the most representative groups belonging to the class Insecta; these findings are consistent with previous investigations conducted in Peru (Ortega et al., 2010; Lujan et al., 2013; Arana and Cabrera, 2017; Carrasco et al., 2020;
TABLE 3 | Phyla of macroinvertebrates by hydrographic slope and aquatic ecosystem, according to research studies carried out between years 1992-2020.

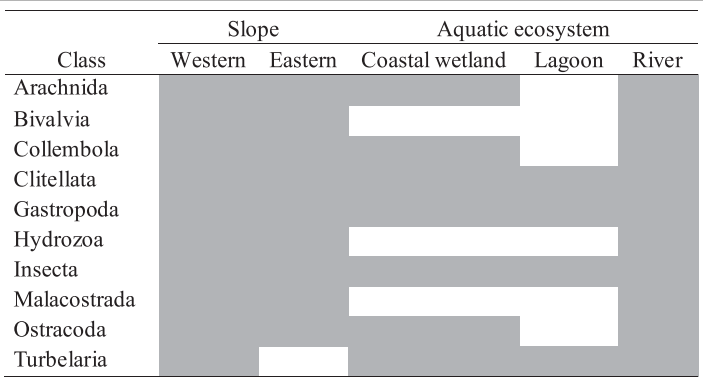

Presence

TABLE 4 | Distribution of macroinvertebrate taxa by hydrographic slope and aquatic ecosystem, according to research studies carried out between years 1992-2020

\begin{tabular}{lccccccc} 
Taxa & \multicolumn{3}{c}{ Aquatic ecosystem } & & \multicolumn{2}{c}{ Slope } \\
\cline { 2 - 4 } & Coastal wetland & Lagoon & River & & Western & Eastern \\
\hline Phylum (No.) & 5 & 4 & 7 & & 7 & 4 \\
Class (No.) & 7 & 4 & 10 & & 10 & 9 \\
Order (No.) & 21 & 10 & 34 & & 39 & 16 \\
Family (No.) & 57 & 12 & 110 & & 116 & 59 \\
\hline
\end{tabular}

Sweeney et al., 2020). Geographically, the western hydrographic slope recorded the highest richness of the different taxonomic categories, probably because most research studies (theses and scientific articles) were conducted in this area (Figure 3).

The phyla Cnidaria, Nematoda, and Nematomorpha were not recorded in the eastern slope (Table 2); also, a smaller number of classes (9) (Table 3) and orders (16) were reported in the eastern versus the western slope (10 and 39, respectively). A similar trend was also observed at the family level; of the 118 families recorded, 59 were reported for the eastern slope. According to the type of aquatic ecosystem, rivers showed the highest number of records for the categories phylum (7), class (10), order (34), and family (110), followed by coastal wetlands with five phyla, seven classes, 21 orders, and 57 families (Table 4).

At the order level, Diptera showed the highest species richness (Table 5), similar to arid zones of northern Chile (Ferru and Fierro, 2015), the Andean centerwest of Argentina (Scheibler, 2008), and the northwest of Argentina (Hankel et al., 2018; Domínguez et al., 2020). Also, the data on the richness of aquatic macroinvertebrates reported to family were arranged systematically, which will facilitate comparisons with studies carried out in similar areas of South America (Palma et al., 2013). These figures may be higher because several studies have been conducted in these environments in the past decade, mainly located in the central coast of Peru, aiming to explore the effects of climate change on the coast of Lima (Aponte, 2017). 
TABLE 5 | Orders of macroinvertebrates by hydrographic slope and aquatic ecosystem, according to research studies carried out between years $1992-2020$.

\begin{tabular}{|c|c|c|c|c|c|c|c|c|c|c|c|}
\hline \multirow{2}{*}{ Order } & \multicolumn{2}{|c|}{ Slope } & \multicolumn{3}{|c|}{ Aquatic ecosystem } & \multirow{2}{*}{ Order } & \multicolumn{2}{|c|}{ Slope } & \multicolumn{3}{|c|}{ Aquatic ecosystem } \\
\hline & Westem & Eastern & $\begin{array}{l}\text { Coastal } \\
\text { wetland }\end{array}$ & Lagoon & River & & Western & Eastern & $\begin{array}{l}\text { Coastal } \\
\text { wetland }\end{array}$ & Lagoon & River \\
\hline Coleoptera & & & & & & Lumbriculida & & & & & \\
\hline Diptera & & & & & & Macrostomorpha & & & & & \\
\hline Ephemeroptera & & & & & & Mesogastropoda & & & & & \\
\hline Hemiptera & & & & & & Neotaenioglossa & & & & & \\
\hline Lepidoptera & & & & & & Oribatida & & & & & \\
\hline Megaloptera & & & & & & Planorbidae & & & & & \\
\hline Odonata & & & & & & Plesioporos & & & & & \\
\hline Orthoptera & & & & & & Podocopida & & & & & \\
\hline Plecoptera & & & & & & Poduromorpha & & & & & \\
\hline Trichoptera & & & & & & Pulmonata & & & & & \\
\hline Anthoathecata & & & & & & Rhabdocoela & & & & & \\
\hline Amphipoda & & & & & & Rhynchobdellida & & & & & \\
\hline Basommatophora & & & & & & Sarcoptiformes & & & & & \\
\hline Caenogastropoda & & & & & & Sorbeoconcha & & & & & \\
\hline Catenulida & & & & & & Stylommatophora & & & & & \\
\hline Decapoda & & & & & & Symphypleona & & & & & \\
\hline Entomobryomorpha & & & & & & Tricladida & & & & & \\
\hline Gordioidea & & & & & & Trombidiformes & & & & & \\
\hline Haplotaxida & & & & & & Veneroida & & & & & \\
\hline Lecithoepitheliata & & & & & & & & & & & \\
\hline
\end{tabular}

: Presence

The families recorded most frequently in both slopes were Chironomidae, Baetidae, Simuliidae, Elmidae, Hydrophilidae, Libellulidae, Physidae, Dytiscidae, Ceratopogonidae, Coenagrionidae, Hydroptilidae, Hydropsychidae, and Tipulidae. On the other hand, the most frequent families considering all types of aquatic ecosystems evaluated were Chironomidae, Baetidae, and Dytiscidae (Table 6).

To note, the cosmopolitan family Chironomidae (Andersen et al., 2000; Sæther and Ekrem, 2003) showed the highest frequency in the study area, consistent with previous studies of arid and semi-arid environments in South America (Scheibler, 2008; Colla et al., 2013; Zelarayán and Salas, 2014; Ferru and Fierro, 2015; Domínguez et al., 2020).

\section{Current and Future Research}

Universidad Nacional Mayor de San Marcos is supervising a number of theses on coastal wetlands. One study has focused on the aquatic macroinvertebrate community in the Regional Conservation Area of Ventanilla Wetlands (Callao), during 2018. In addition, two theses are ongoing to evaluate the conservation status of the El Paraíso Coastal Wetland (Lima) considering aquatic communities, macroinvertebrates included. On the other hand, for lotic ecosystems, there is a thesis on biodiversity and bioindication of macroinvertebrates in the Chancay River, Province of Santa Cruz, Cajamarca, which is in the taxonomic identification stage, and another on the altitudinal distribution in the Chuschama gorge, Sucre Province, Ayacucho.

Since 2016, the Universidad Nacional de San Agustín de Arequipa has strongly supported scientific research in various lines of research, e.g., Limnology. Four projects are ongoing: "Ecological status and environmental variability of the Tambo Basin through the study of aquatic communities as part of integrated management"; "Selection and adaptation of biotic indices for the assessment of the ecological status of the Sihuas and Vitor rivers in the southwestern slope of Peru"; and another two addressing the pollution of lotic systems and the physicochemical characterization of metals and agrochemicals in water, sediments, and the trophic chain of Criphiops caementarius in the Tambo, Camaná-Majes, and Ocoña rivers.

To continue advancing the scientific knowledge on aquatic macroinvertebrates, research work should focus on taxonomy and identification of these organisms, particularly on immature stages of aquatic insects, as well as platyhelminthes, molluscs, and annelids; this requires providing proper training to future taxonomy specialists. Besides, taxonomic keys are needed for the various macroinvertebrate groups inhabiting rives and wetlands along the Peruvian coast; these will facilitate conducting basic research on systematics and biodiversity, which in turn contribute to the identification of biomarkers. 
TABLE 6 | Families of macroinvertebrates by hydrographic slope and aquatic ecosystem, according to research studies carried out between years $1992-2020$.

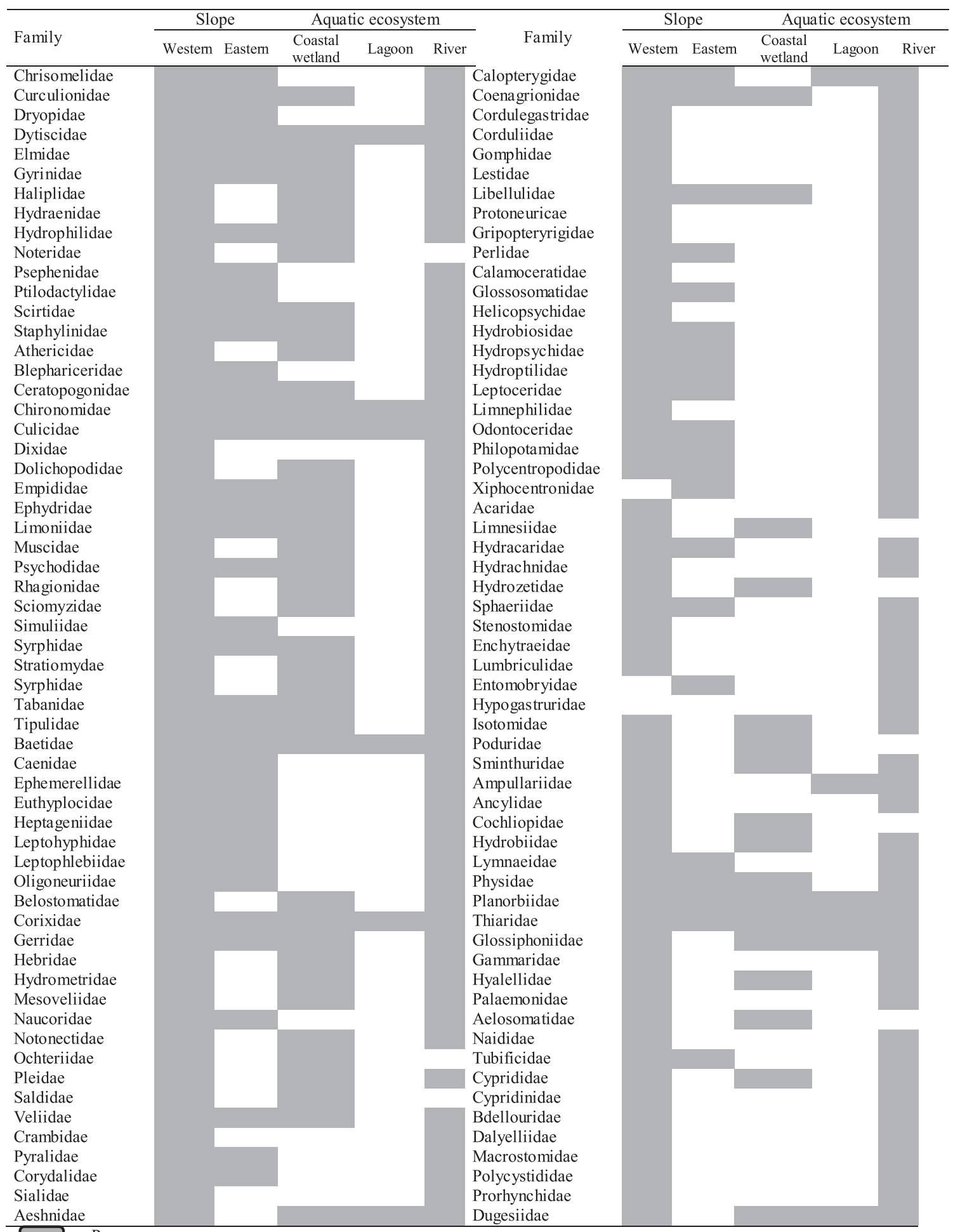


Also needed are studies addressing the functional structure of macroinvertebrates to gain a deeper understanding of ecological processes and the participation of these organisms in the functioning of the Peruvian arid and semi-arid ecosystems. As regards bioindicators, research is needed on the calibration of the indices currently available (ABI, BMWP, etc.) for lotic and lentic environments of the hydrographic basins in arid and semi-arid areas. The geological, geographic, and climatic conditions that characterize these ecosystems are unique, subject to highly variable large-scale weather events such as $\mathrm{El} \mathrm{Niño} \mathrm{and} \mathrm{La}$ Niña. For this reason, future studies should also explore the relationships between environmental variability and the patterns of abundance, richness, and distribution of aquatic macroinvertebrates. The development of networks of scientists working on these topics should be encouraged, including scientific meetings of Peruvian specialists to address future studies in the northern and southern areas of Peru, aiming to obtain further information on the ecology of aquatic macroinvertebrates in these areas.

Further support should be provided to studies addressing taxonomic and ecological aspects of macroinvertebrates in the eastern slope and to the departments with the lowest number of research studies as there are limited studies currently available, probably for the lack of specialists and economic resources in research institutions, as well as access to potential study areas, broadening the thematic approach to an integral ecosystemoriented perspective, and calibrating and validating biotic indexes for the major hydrographic basins.

Last but not least, we propose the elaboration of a national database chartered by a Peruvian agency such as the Ministry of the Environment to gather information on the diversity of the taxonomic groups of aquatic macroinvertebrates, in partnership with academic institutions conducting research on this field, as indicated in Figure 7.

This work represents an early effort to review, systematize, analyze, and gather the results of the various studies on aquatic macroinvertebrates in Peru, particularly in arid and semi-arid ecosystems. Likewise, it contributes valuable information to the

\section{REFERENCES}

Andersen, T., Contreras-Ramos, A., and Spies, M. (2000). "Chironomidae (Diptera)," in En Biodiversidad, taxonomía y biogeografía de artrópodos de México: Hacia una síntesis de su conocimiento. Editors J. L. Bousquets, E. G. Soriano, and N. Papavero (México DF, México: Universidad Nacional Autonoma de Mexico), 2, 581-591.

Aponte, H. (2017). Humedales de la Costa Central del Perú. Un diagnóstico de los humedales Santa Rosa, laguna El Paraíso y Albufera de Medio Mundo. Lima, Perú: Cooperacción, 114

Arana, J., and Cabrera, C. (2017). Macroinvertebrados Acuáticos y Caracterización Ecológica de los Ambientes Dulceacuícolas del área de Influencia del Gasoducto PERÚ LNG en los Departamentos de Ica y Huancavelica. Revista Del. Instituto de Investigación de La Facultad de Ingeniería Geológica, Minera, Metalúrgica Geográfica 20 (40), 86-93. doi:10.15381/iigeo.v20i40.14394

Barbosa, J. E. D. L., Medeiros, E. S. F., Brasil, J., Cordeiro, R. D. S., Crispim, M. C. B., and Silva, G. H. G. D. (2012). Aquatic Systems in Semi-Arid Brazil: Limnology and Management. Acta Limnol. Bras. 24 (1), 103-118. doi:10.1590/S2179975X2012005000030 knowledge of aquatic biodiversity and its distribution in these types of ecosystems for Latin America, in addition to the studies recently conducted in Argentina (Hankel et al., 2018; Domínguez et al., 2020), Venezuela (Rodríguez, 2020), Colombia (González and Moreno, 2017; Roldán, 2020), Mexico (López-López et al., 2019), Ecuador (Valdiviezo-Rivera et al., 2018), Brazil (Barbosa et al., 2012), Chile (Valdovinos, 2008), and Bolivia (Rocabado, 2003).

\section{AUTHOR CONTRIBUTIONS}

Writing-original draft preparation; Review and editing. JAM, CCB, PCP, CRC, and MSP.

\section{ACKNOWLEDGMENTS}

To the Natural History Museum of the Universidad Nacional Mayor de San Marcos, the Regional Government of Callao, the Regional Government of Lima, and the Association Defensa Bandurria Paraíso. Special thanks also go to the Vice-rectorate for Research, the Biodiversity and Geographic Information System Laboratory (BioSIG), and the Center for Research in Ecosystems and Aquatic Biodiversity (CI-EBACUA) of the Universidad Nacional de San Cristobal de Huamanga for logistical support. Finally, thanks to the Hydrobiology Laboratory at the Universidad Nacional de San Agustín de Arequipa and to Antonio Oswaldo Murrugarra Arévalo for support throughout this research. María Elena Sánchez-Salazar translated the manuscript into English.

\section{SUPPLEMENTARY MATERIAL}

The Supplementary Material for this article can be found online at: https:/www.frontiersin.org/articles/10.3389/fenvs.2021.658940/ full\#supplementary-material

Brack, A., and Mendiola, C. (2000). Ecología del Perú. Lima, Perú: Bruño. Available at: https://agris.fao.org/agris-search/search.do?recordID=US201300056262 (Accessed December 20, 2020).

Carrasco, C., Rayme, C., Alarcóndel, R. D. P. P., Ayala, Y., Arana, J., and Aponte, H. (2020). Macroinvertebrados Acuáticos en Arroyos asociados con bofedales altoandinos, Ayacucho Perú. Revista de Biología Trop. 68 (S2), S116-S161. doi:10.15517/rbt.v68iS2.44344

Colla, M., César, I., and Salas, L. (2013). Benthic Insects of the El Tala River (Catamarca, Argentina): Longitudinal Variation of Their Structure and the Use of Insects to Assess Water Quality. Braz. J. Biol. 73 (2), 357-366. doi:10.1590/ S1519-69842013000200016

Contador, T. A., Kennedy, J. H., and Rozzi, R. (2012). The Conservation Status of Southern South American Aquatic Insects in the Literature. Biodivers Conserv 21 (8), 2095-2107. doi:10.1007/s10531-012-0299-x

Da Cruz Sousa, R., and Ríos-Touma, B. (2018). Stream Restoration in Andean Cities: Learning from Contrasting Restoration Approaches. Urban Ecosyst. 21 (2), 281-290. doi:10.1007/s11252-017-0714-x

Domínguez, E., Giorgi, A., and Gómez, N. (2020). La bioindicación en el monitoreo y evaluación de los sistemas fluviales de la Argentina. Bases para el análisis de la integridad ecológica. Buenos Aires, Argentina: Universitaria de Buenos Aires. 
D. Rodríguez (Editors) (2020). Ríos en Riesgo de Venezuela. Volumen 3. Colección Recursos hidrobiológicos de Venezuela. Universidad Centroccidental Lisandro Alvarado (UCLA). Available at: https://www.academia.edu/42252567/R\%C3\% ADos_en_Riesgo_de_Venezuela_Volumen_3 (Accessed May 28, 2021).

Ferreras-Fernández, T., García-Peñalvo, F. J., and Merlo-Vega, J. A. (2015). "Open Access Repositories as Channel of Publication Scientific Grey Literature," in Third International Conference on Technological Ecosystems for Enhancing Multiculturality (TEEM'15, Porto, Portugal, October 15, 2015 (Association for Computing Machinery). doi:10.1145/2808580.2808643

Ferru, M., and Fierro, P. (2015). Estructura de macroinvertebrados acuáticos y grupos funcionales tróficos en la cuenca del río Lluta, desierto de Atacama, Arica y Parinacota, Chile. Idesia 33 (4), 47-54. doi:10.4067/S071834292015000400007

GEO GPS PERÚ (2014). Cuencas Hidrográficas del Perú. Oficina Nacional de Evaluación de Recursos Naturales - INRENA - ONERN - MINAM. Available at: https://www.geogpsperu.com/2014/02/descargar-cuencas-hidrograficas-del. html (Accessed December 19, 2020).

GEO GPS PERÚ (2015). Mapa de Zonas de Vida. Oficina Nacional de Evaluación de Recursos Naturales - INRENA - ONERN - MINAM. Available at: https://www.geogpsperu.com/2015/10/mapa-de-zonas-devida-onern-online.html (Accessed December 19, 2020).

González, H. Z., and Moreno, M. A. Z. (2017). Macroinvertebrados acuáticos epicontinentales en ecosistemas lóticos del Valle del Patía. Revisión de literatura científica 1991- 2015. Revista Novedades Colombianas 12 (1), 22-86.

Guerrero, A. M., Rodríguez, E. F., Leiva, S., and Pollack, L. E. (2019). Zonas de vida en el proceso de la Zonificación Ecológica Económica (ZEE) de la provincia de Trujillo, región La Libertad, Perú. Arnaldoa 26 (2), 761-792. doi:10.22497/ arnaldoa.262.26217

Hankel, G. E., Emmerich, D., and Molineri, C. (2018). Macroinvertebrados bentónicos de ríos de zonas áridas del noroeste argentino. Ecol. Austral 28, 435-445. doi:10.25260/EA.18.28.2.0.645

Holdridge, L. R. (1987). Ecología basada en zonas de vida. Agroamerica.

INEI (2020). Estado de la población peruana 2020. Instituto Nacional de Estadística e Informática-INEI. Available at: https://www.inei.gob.pe/media/ MenuRecursivo/publicaciones_digitales/Est/Lib1743/Libro.pdf.

López-López, E., Sedeño-Díaz, J. E., Mendoza-Martínez, E., Gómez-Ruiz, A., and Martínez Ramírez, E. (2019). Water Quality and Macroinvertebrate Community in Dryland Streams: The Case of the Tehuacán-Cuicatlán Biosphere Reserve (México) Facing Climate Change. Water 11 (7), 1376. doi:10.3390/w11071376

Lujan, N. K., Roach, K. A., Jacobsen, D., Winemiller, K. O., Vargas, V. M., Ching, V. R., et al. (2013). Aquatic Community Structure across an Andes-to-Amazon Fluvial Gradient. J. Biogeogr. 40 (9), 1715-1728. doi:10.1111/jbi.12131

Masson, L. (2002). El recurso agua en el Perú: Problemas Perspectivas. En el medio ambiente en el Perú 2001, 37-74.

McDonald, R. I., Douglas, I., Revenga, C., Hale, R., Grimm, N., Grönwall, J., et al. (2011). Global Urban Growth and the Geography of Water Availability, Quality, and Delivery. Ambio 40 (5), 437-446. doi:10.1007/s13280-011$0152-6$

Meyer, J. L., Paul, M. J., and Taulbee, W. K. (2005). Stream Ecosystem Function in Urbanizing Landscapes. J. North Am. Benthological Soc. 24 (3), 602-612. doi:10.1899/04-021.1

MINAM (2015a). Mapa Nacional de Cobertura Vegetal: Memoria descriptiva. Lima, Perú: Ministerio del Ambiente, 108.

MINAM (2019a). Mapa Nacional de Ecosistemas del Perú: Memoria descriptiva. Ministerio del Ambiente. Available at: https://sinia.minam.gob.pe/mapas/ mapa-nacional-ecosistemas-peru (Accessed December 8, 2020).

MINAM (2019b). Sexto informe nacional sobre diversidad biológica. La biodiversidad en cifras. Lima, Perú: Ministerio del Ambiente.

MINAM (2015b). Vertientes y disponibilidad de agua. Available at: https://www. minagri.gob.pe/portal/42-sector-agrario/recurso-agua/324-vertientes-y-disponibilidadde-agua (Accessed December 8, 2020).

Montgomery, M. A., and Elimelech, M. (2007). Water and Sanitation in Developing Countries: Including Health in the Equation. Environ. Sci. Technol. 41 (1), 17-24. doi:10.1021/es072435t

Municipalidad Provincial del Callao (2013). Ubicación geográfica de la provincia del Callao. Available at: https://www.municallao.gob.pe/index.php/laprovincia/ubicacion-geografica (Accessed December 20, 2020).
ONERN (1976). Mapa ecológico del Perú: Guía explicativa. Lima, Perú: Oficina Nacional de Evaluación de Recursos Naturales, 271.

Oré, M. T., Bayer, D., Chiong, J., and Rendon, E. (2012). Emergencia hídrica explotación del acuífero en un valle de la Costa peruana: El caso de Ica, Perú. Medio Ambiente y Urbanización 77 (1), 213-234.

Ortega, H., Chocano, L., Palma, C., and Samanez, I. (2010). Biota acuática en la Amazonía Peruana: Diversidad y usos como indicadores ambientales en el Bajo Urubamba (Cusco - Ucayali). Revista Peruana de Biología 17 (1), 29-36. doi:10.15381/rpb.v17i1.47

Palma, A., González-barrientos, J., Reyes, C. A., and Ramos-jiliberto, R. R. (2013). Biodiversidad y estructura comunitaria de ríos en las zonas árida, semiárida y mediterránea-norte de Chile. Rev. Chil. Hist. Nat. 86 (1), 1-14. doi:10.4067/ S0716-078X2013000100001

Programa de Cooperación Interuniversitaria e Investigación Científica entre España e Iberoamérica (2011). Desarrollo de un sistema participativo sobre la calidad ecológica de los ríos en la región de Cajamarca (AP/036126/11). Available at: https://www.udc.es/export/sites/udc/ori/_galeria_down/infprofesores/ programa_cooperacion_universitaria/Listado_de_preseleccionados_PCI_2011_ 271011.pdf_2063069239.pdf (Accessed May 28, 2021).

Ramírez, A., and Gutiérrez-Fonseca, P. E. (2014). Estudios sobre macroinvertebrados acuáticos en América Latina: avances recientes y direcciones futuras. Revista de Biología Trop. 62, 9-20. doi:10.15517/rbt.v62i0.15775

Ramírez, A., and Gutiérrez-Fonseca, P. E. (2020). Freshwater Research in Latin America: Current Research Topics, Challenges, and Opportunities. Revista de Biología Trop. 68 (S2), S1-S12. doi:10.15517/rbt.v68iS2.44328

Ríos-Touma, B., Acosta, R., and Prat, N. (2014). The Andean Biotic Index (ABI): Revised Tolerance to Pollution Values for Macroinvertebrate Families and Index Performance Evaluation. Revista de Biología Trop. 62, 249-273. doi:10.15517/rbt.v62i0.15791

Ríos-Touma, B., and Ramírez, A. (2019). "Multiple Stressors in the Neotropical Region: Environmental Impacts in Biodiversity Hotspots," in En Multiple Stressors in River Ecosystems (Quito, Ecuador: Elsevier), 205-220. doi:10.1016/B978-0-12-811713-2.00012-1

Rocabado, G. B. (2003). Ecología y distribución de invertebrados acuáticos en ríos andinos de la cuenca amazónica boliviana. Tesis Doctoral, Universidad Nacional de Tucuman. Available at: https://horizon.documentation.ird.fr/ exl-doc/pleins_textes/divers17-11/010039294.pdf (Accessed May 28, 2021).

Roldán, G., and Ramírez, J. J. (2008). Fundamentos de limnología neotropical. 2.a ed. Medellín, Colombia: Universidad de Antioquia.

Roldán, G. (2020). Revisión histórica de la limnología en Colombia. Rev. Acad. Colomb. Cienc. Ex. Fis. Nat. 44 (171), 303-328. doi:10.18257/raccefyn.1056

Roldán-Pérez, G. (2016). Los macroinvertebrados como bioindicadores de la calidad del agua: cuatro décadas de desarrollo en Colombia y Latinoamerica. Rev. Acad. Colomb. Cienc. Ex. Fis. Nat. 40 (155), 254-274. doi:10.18257/raccefyn. 335

Roy, A. H., Capps, K. A., El-Sabaawi, R. W., Jones, K. L., Parr, T. B., Ramírez, A., et al. (2016). Urbanization and Stream Ecology: Diverse Mechanisms of Change. Freshw. Sci. 35 (1), 272-277. doi:10.1086/685097

Salazar, B. (2012). El secreto del boom del espárrago: La sobreexplotación del agua. La Revista Agraria 139, 10-12.

Sæther, O. A., and Ekrem, T. (2003). Biogeography of Afrotropical Chironomidae (Diptera), with Special Reference to Gondwanaland. Cimbebasia. Limnologica 81, 125759. doi:10.1016/j.limno.2020.125759

Scheibler, É. E. (2008). Biodiversidad de insectos acuáticos en zonas áridas del centro-oeste andino (Mendoza, Argentina). Cuadernos de Biodiversidad 25, 19-26. doi:10.14198/cdbio.2008.25.03

Sweeney, B. W., Battle, J. M., Funk, D. H., Flowers, W. R., Ojeda, T. G., Huamantinco, A., et al. (2020). Evaluating Water Quality for Amazonian Streams along the Interoceanic Highway in Peru Using Macroinvertebrates Collected by Hand and with Leaf Packs. Limnologica 81, 125759. doi:10.1016/ j.limno.2020.125759

Urteaga-Crovetto, P. (2016). Between Water Abundance and Scarcity: Discourses, Biofuels, and Power in Piura, Peru. Antipode 48 (4), 1059-1079. doi:10.1111/ anti.12234

Valdiviezo-Rivera, J., Garzón Santomaro, C., Inclán Luna, D., Jaén, J., and Gonzalez-Romero, D. (2018). Ecosistemas Dulceacuicolas de la provincia de El Oro: Peces y macroinvertebrados acuáticos como indicadores biológicos del Páramo al Manglar. Publicación Miscelánea $\mathrm{N}^{\circ}$ 10: Serie 
de Publicaciones GADPEO - INABIO. Available at: https://www. researchgate.net/publication/334001027_Ecosistemas_Dulceacuicolas_de_la_ provincia_de_El_Oro (Accessed May 27, 2021).

Valdovinos, C. (2008). Invertebrados dulceacuícolas. En Biodiversidad de Chile Patrimonio $y$ desafíos. 2.a ed. Santiago, Chile: CONAMA, 202-224. Available at: http://www.ocholibros.cl/libro/biodiversidad-de-chilepatrimonio-y-desafn-os_57 (Accessed May 27, 2021).

Velazco, J., and Pinilla, V. (2018). "Development Models, Agricultural Policies and Agricultural Growth: Peru, 1950-2010," in Agricultural Development in the World Periphery: A Global Economic History Approach. Editors E. V. Pinilla and H. Willebald (Lima, Perú: Springer International Publishing), 413-438. doi:10.1007/978-3-319-66020-2_16

Vidal-Abarca, M. R., Gómez, R., and Suárez, M. L. (2004). Los ríos de las regiones semiáridas. Revista Ecosistemas 13 (1), 16-28. doi:10.7818/re.2014.13-1.00

VLIR-UOS (2018). Impact on Surface Water Resources and Aquatic Biodiversity by Opencast Mining Activities in Cajamarca, Peru. Lima, Perú: Vliruos. Available at: https://www.vliruos.be/en/projects/project/22.

Walsh, C. J., Roy, A. H., Feminella, J. W., Cottingham, P. D., Groffman, P. M., and Morgan, R. P. (2005). The Urban Stream Syndrome: Current Knowledge and the Search for a Cure. J. North Am. Benthological Soc. 24 (3), 706-723. doi:10.1899/04-028.1
Zelarayán, G., and Salas, L. (2014). Estructura y Variación Espacial de las Colectividades de Artrópodos en el Río "Las Juntas" (Catamarca, Argentina). Huayllu-Bios 8, 15-39.

Conflict of Interest: The authors declare that the research was conducted in the absence of any commercial or financial relationships that could be construed as a potential conflict of interest.

Publisher's Note: All claims expressed in this article are solely those of the authors and do not necessarily represent those of their affiliated organizations, or those of the publisher, the editors and the reviewers. Any product that may be evaluated in this article, or claim that may be made by its manufacturer, is not guaranteed or endorsed by the publisher.

Copyright (C) 2021 Arana Maestre, Carrasco Badajoz, Coayla Peñaloza, Rayme Chalco and Sánchez Peña. This is an open-access article distributed under the terms of the Creative Commons Attribution License (CC BY). The use, distribution or reproduction in other forums is permitted, provided the original author(s) and the copyright owner(s) are credited and that the original publication in this journal is cited, in accordance with accepted academic practice. No use, distribution or reproduction is permitted which does not comply with these terms. 